\title{
Nem morto nem eterno: o jornal à busca de um destino
}

Juliana Doretto

\section{Resumo:}

Resenha do livro $O$ destino do jornal

\section{Palavras Chave:}

Lourival Sant'Anna, jornalismo, internet

\section{Abstract:}

Book review $O$ destino do jornal

\section{Keywords:}

Lourival Sant'Anna, journalism, internet

\section{SANT'ANNA, Lourival. O destino do jornal. Rio de Janeiro: Record, 2008.}

As bancas de jornal podem perder o nome dentro de alguns anos. Se os diários não puderem ser mais pendurados nessas lojas, oferecidos como mercadoria fresca do dia, o complemento nominal perderá o significado. Talvez os jornais se reinventem, se transformando em arquivos enviados pela internet. Ou, quem sabe sejam sufocados pelos novos formatos midiáticos trazidos pelas tecnologias.

Conduzido por essa dúvida, o jornalista e repórter especial de «O Estado de S.Paulo» Lourival Sant'Anna investiga, em sua dissertação de mestrado, agora transformada em livro, o cenário atual e as perspectivas de três grandes jornais brasileiros - «Folha de S. Paulo», «O Globo» e do próprio «Estado».

O jornalista justifica a sua escolha por serem jornais com grandes índices de circulação, terem padrões empresariais e logísticos parecidos e conseguirem projetar-se como nacionais, na distribuição, nos assuntos tratados e na influência.

Sem buscar conclusões, mas, acertadamente, tentando apenas identificar tendências em um universo em constante mutação, Sant'Anna desenvolve seu trabalho sobre um tripé de transformações no mercado jornalístico mundial: o acirramento da concorrência, a mudança dos hábitos de leitura, e a inovação.

No primeiro, o autor diz que "a queda na circulação dos jornais coincidiu, nos últimos anos, com o surgimento e a expansão da internet, com o crescimento da TV por assinatura, com o aumento do espaço dado ao jornalismo nas emissoras de rádio e com a criação, em 1998, de uma nova revista semanal de grande circulação no Brasil, a «Época»" (SANT’ANNA, 2008: 153).

No segundo item, a mudança na leitura, o autor usa pesquisas quantitativas para mostrar que decrescem o número de exemplares por mil habitantes adultos (no Brasil, entre 2001 e 2005, foi de $64 \%$ para 45\%, segundo a Associação Nacional de Jornais) e o tempo em que os leitores de jornal se dedicam a ele (de 64 minutos em 2011 para 46 em 2006 - os números também são da associação). 
O último elemento, a inovação da tecnologia, transforma as técnicas de apuração e confecção da notícia bancos de dados e informação em rede, partilhadas - e abre a possibilidade de convergência com outros meios. Neste último aspecto, os jornais brasileiros estão ainda apenas no estágio da transposição, sem muitas modificações das notícias do impresso para a internet. Mas o autor aponta que os veículos parecem caminhar para a integração entre as redações de diários e seus portais.

Esse tripé foi motivo de entrevistas com os diretores de redação dos três periódicos, que apresentaram opiniões semelhantes - apenas um deles, Sandro Vaia, de «O Estado», deixou o cargo. Trechos das conversas aparecem ao longo do texto, mas todas elas foram publicadas na íntegra em forma de anexo do livro. Vale consultá-las: a habilidade em perguntar, fazendo com que, de modo indireto, esses dirigentes dialogassem sobre o estágio atual do jornalismo brasileiro, relembra ao leitor de que o livro se trata de (bom) trabalho de jornalista.

Nesse ponto, faltou, talvez, situar melhor a posição desses diretores dentro de seus jornais, para os leitores que não estão tão familiarizados com o universo do mercado jornalístico brasileiro. Há quanto tempo estavam no jornal? Por quais lugares passaram ao longo de suas carreiras? Até que ponto suas tomadas de decisão são autônomas em relação à direção empresarial do jornal? Respostas a essas perguntas ajudariam a relativizar ou a reforçar os dados trazidos pelos entrevistados.

Também por meio de entrevistas, Santa'Anna dá voz a dois importantes pesquisadores internacionais no campo das novas mídias: Ramón Salaverría, diretor do Laboratório de Comunicação Multimídia da Universidade de Navarra (Espanha) e Nicholas Negroponte, diretor do Media Lab do Massachusetts Institute of Technology.

Para esses estudiosos, a migração do suporte papel para a tela está muito mais visível no horizonte do que para os diretores de redação entrevistados. Mas eles acreditam que o novo material a ser utilizado não vai aniquilar a necessidade da presença do - bom - jornalismo. Negroponte diz que "a maioria das matérias em um jornal é importante por causa do ponto de vista sobre o fato, não por causa do evento em si, quantas pessoas estiveram envolvidas, quantas pessoas morreram ou citações precisas" (SANT'ANNA, 2008: 174).

Nessa parte do livro, sente-se a ausência de uma revisão bibliográfica aprofundada desses autores, que dialogaria com as conversas pessoais. As idéias principais dos autores estão em seus textos, e a entrevistas, fruto do esforço do pesquisador, poderiam servir para elucidar dúvidas conceituais, propor novos aspectos de discussão e provocar o confronto com outros pesquisadores.

\section{O papel da audiência}

Dentro do material utilizado por Santa'Anna no seu trabalho, um presente a outros pesquisadores: o autor teve acesso a um estudo de «focus group», método em que um grupo de pessoas discute temas e responde a questões propostos por um mediador. São pesquisas utilizadas por grandes publicações, mas, por serem estratégicas às decisões dessas empresas, seus dados não costumam ser públicos. Santa'Anna não pôde revelar o nome do jornal brasileiro que encomendou a pesquisa, mas isso não diminuiu as possibilidades de investigação que essas informações abrem aos estudiosos nacionais.

Desse «focus group» a credibilidade surge como uma das principais qualidades do jornal impresso. Um valor intangível, cujo alcance, apesar de ser difícil de se estudar - como demonstra Sant'Anna ao trazer pesquisas de Philip Meyer e Alfonso Sánchez-Tabernero - é lembrado tanto por aqueles que gostam dos jornais quanto pelos que não os apreciam. O jornal aparece como o meio mais completo, o mais profundo e que traz as informações mais confiáveis. Um porto seguro, que, em meio a um bombardeio cada vez maior de notícias e informações, trazidas pelos mais diferentes veículos, contextualiza, dá sentido e hierarquiza os dados. As 
revistas também teriam esse perfil analítico, mas com um ponto negativo em relação aos jornais impressos: a periodicidade semanal torna essa publicação menos atual ou mais "fria” (no jargão jornalístico) do que o jornal.

Porém a pesquisa mostra também que os diários impressos são, ao mesmo tempo, considerados “duros", com linguagem e assuntos mais sisudos. "Assim, o jornal parece ter assegurado o seu lugar, desde que faça algumas concessões ao prazer do leitor, e não siga comportando-se com se ele fosse obrigado a digeri-lo", escreve (SANT’ANNA, 2008: 85).

Quais seriam as concessões e até que ponto serão ou deverão ser feitas? Em primeiro lugar, a "casa" parece estar novamente arrumada nos departamentos financeiros dos jornais. O autor mostra, na conclusão do livro, que após quedas na circulação do início da década até 2003, os diários retomavam a curva ascendente nas vendas. Após enfrentarem dívidas galopantes com a desvalorização do real frente ao dólar, em 1999, geradas por investimentos em novas áreas tecnológicas que não tiveram a rentabilidade esperada, as finanças dos jornais parecem voltar ao equilíbrio. Apesar de as verbas publicitárias estarem migrando aos novos meios (o jornal tinha, em 2001, 21\% do investimento publicitário no País; em 2006, caiu para 14\%, segundo dados da Associação Nacional de Jornais), os anunciantes continuam achando que a credibilidade da informação dos diários é transferida, pelo leitor, às propagandas nele impressas. E isso não é pouco.

Certas demandas os diretores de redação não estão dispostos a atender. Eles acreditam que não devem fazer como as revistas, que têm investido pesado em temas como saúde e vaidade, por serem os mais pedidos pelos leitores em suas pesquisas qualitativas. Os jornais pensam que, apesar de áridos, temas politizados são de importância pública e não podem ser abandonados, apesar de admitirem a necessidade de se aproximar mais do dia-a-dia de seu leitorado.

Por outro lado, os jornais parecem ainda falar para um leitor que não teve acesso às notícias de ontem realidade inimaginável num mundo com rádio, TV e internet. Os diretores estão conscientes disso e pretendem mudar o foco dos seus diários para o que fazem de melhor: o contexto, a explicação e a história inovadora e bem contada. E isso envolve investimento em qualidade, como coberturas extensas e contratação de bons profissionais. Eis aí um desafio aos diretores de redação, segundo Sant'Anna: convencer as áreas financeiras das empresas a investir em setores que não dão retorno econômico imediato.

Sobre a migração do suporte papel para o «on-line», Sant’Anna diz que não há dados para apostar em um caminho, mas ressalva que, se a transposição for feita, os jornais enfrentarão dificuldade para explorar uma das maiores inovações da internet: a interatividade com os leitores, que altera a relação emissor-receptor e possibilita ao leitor hierarquizar as notícias à sua maneira, desequilibrando o status da edição jornalística como é feita hoje. Segundo o autor, se os diários não aprenderem a conviver com esse novo leitor, mais participativo e próximo, mas que não deixa de reconhecer o poder analítico dos jornais, outros veículos poderão fazê-lo, levando consigo uma parte do público.

Por fim, costurados todos esses aspectos da questão, que se desenrolam no mesmo momento em que o autor os estuda, parece acertada a decisão do jornalista do «Estado» ao escrever que "há a decretação da morte do jornal. E há o seu oposto: a convicção de sua eternidade. A verdade provavelmente reside em algum ponto entre os dois extremos" (SANT'ANNA, 2008: 180). 


\section{Bibliografia:}

SANT'ANNA, Lourival. O destino do jornal. Rio de Janeiro: Record, 2008.

\section{Mini Currículo :}

Bacharel em Comunicação Social, com habilitação em Jornalismo, pela Escola de Comunicação e Artes da Universidade de São Paulo (ECA-USP) e mestranda do Programa de Pós-Graduação em Ciências da Comunicação pela mesma instituição 